\section{Plain English Campaign Award for the College}

The College was delighted to learn recently that two of the Help is at Hand leaflets, Sleep Problems and Bereavement had recetved Plain English Campaign Awards for 1996. Professor Brice Pitt, former Director of Public Education, and $\mathrm{Dr}$ Guinevere Tufnell, a long-standing member of the Public Education Committee, attended the Awards Ceremony at the Whitbread Brewery Conference Centre in London on Monday 18 November to receive the plaque on behalf of the College. The leaflets had been nominated by members of the general public for providing clear and understandable information on these common but sensitive issues.

\section{The Communication Award}

The BUPA Foundation Award for effective communication with patients, in association with the Academy of Medical Royal Colleges and the Patients Association, is now inviting entries for the 1997 Award. Entries, which may cover any or all of the categories of the Medical Royal Colleges or their faculties, are now canvassed from Members and Fellows of the Colleges. They will be considered by a panel of lay and medical judges chaired by a medical journalist. The result will be announced, and the presentation made, at a ceremony at Lincoln's Inn on the 12 November 1997. Further information: Lady Nourse, 12 Old Square, Lincoln's Inn, London WC2A 3TX (Tel: 0171404 0809; Fax 0171831 8096).

\section{Saint Vincent Prize}

This prize can be awarded to individuals, societies or institutions in the European Union for research, care-giving and/or preventive methods with reference to severe and profound mental retardation. Letters of application, to be submitted before 1 May 1997, should comprise a short CV of the candidates; or, in the case of a society or institution, a CV of its representative(s), along with a short history of the organisation. Six copies of a detalled description of the proposal should also be submitted before 1 July 1997. Applications should be sent to: Professor A. E. Baert, Sint Vicentius Fonds vzw, Leernesteenweg 53. B-9800 Deinze (E-mail: pub01482@innet.be).

\section{New publications}

The Royal College of Psychiatrists has produced a series of 21 factsheets, Mental Health and Growing Up, which aim to provide practical upto-date information about the emotional and psychiatric disorders affecting children and young people. Copies are available for $£ 7.50$ from the publications department, The Royal College of Psychiatrists, 17 Belgrave Square, London SW1X 8PG (Cheques to be made payable to the Royal College of Psychiatrists).

The Mental Health Charity MIND has recently published a new booklet in their How to ... series entitled How to recognize the early signs of mental distress. This is available for $\& 1$ from MIND publications, 15-19 Broadway, Stratford, London E15 4BQ (please enclose a 31p SAE with orders). MIND have also recently published a report entitled Not Just Sticks and Stones, highlighting the harassment, abuse and discrimination suffered by people with mental health problems. Copies may be obtained by contacting Sue Baker in MIND's press office on 01815221743.

A report, Issues arising from professional conduct complaints, produced by the UKCC describes trends in the professional conduct cases considered by the UKCC and sets out an agenda for action by employers and managers in the health services. Copies are available free of charge and in unlimited quantities from the Distribution Department, UKCC, 23 Portland Place, London WIN 4JT.

The British Migraine Association have produced a new leaflet giving helpful advice on how to cope with migraine, written in five Asian languages. Copies are available free of charge from the British Migraine Association, Department AL, 178A High Road, Byfleet, West Byfleet, Surrey KT14 7ED (please enclose a 31p 9" × 6" SAE with orders).

The Alzheimer's Disease Society have published The Carers Resource Book for Younger People with Dementia, providing up-to-date advice for carers in the areas of law, employment, finance and daily living. This is available for $£ 10$ to healthcare professionals and $£ 5$ for carers, from The Alzheimer's Disease Society, Gordon House, 10 Greencoat Place, London SWIP IPH. 